\title{
Research article \\ Clinical and biomarker profile of COVID-19 patients admitted in a tertiary care hospital
}

Archana Bhat ${ }^{1}$, Don Gregory Mascarenhas ${ }^{2}$, Manjunath J. ${ }^{3}$, Anand Kumar R. ${ }^{4}$, Sucharitha Suresh ${ }^{5}$ Glenn Fernandes $^{6}$

${ }^{1}$ Assistant Professor of Pathology, ${ }^{2}$ Associate Professor of Pulmonology, ${ }^{3}$ Professor and Head of Nephrology, ${ }^{4}$ MD Resident of Internal Medicine, ${ }^{5}$ Professor of Community Medicine and Statistics, ${ }^{6}$ Assistant Professor of Internal Medicine, Father Muller Medical College, Mangalore, Karnataka, India

\author{
(Received: January $2021 \quad$ Revised: April $2021 \quad$ Accepted: April 2021)
}

Corresponding author: Archana Bhat. Email: archibhat3@gmail.com

\begin{abstract}
Introduction and Aim: A novel beta-coronavirus emerged in Wuhan, China during the early December 2019 and spread globally. The clinical signs and symptoms and the disease severity in people infected with COVID-19 can be varied. The present study was conducted to study the biomarker profile and their association with disease severity in COVID-19.

Materials and Methods: This was a single-centre Cohort study of data regarding epidemiological, clinical and biomarker parameters, and outcome of COVID-19 patients admitted in a tertiary care hospital in South India. CDC guidelines were followed for assessing disease severity.

Results: A total of 336 COVID-19 patients were admitted during the study period. Of these 16 were excluded and 320 cases were analysed. Mean age of patients was 44.82 years. A male predominance was observed. Diabetes mellitus was the most common co-morbidity. Asymptomatic, Mild, moderate, severe and critical disease was seen in $15 \%, 52.5 \%, 20.3 \%, 6.3 \%$ and $5.9 \%$ patients respectively. ICU care was required in $15.3 \%$. Overall mortality was 5.3\%. The mean NLR, ALC, CRP, LCR, LDH, Ferritin and D-dimer in the severe group vs non-severe group were 19.03 vs $4.2,1025$ cells/cu mm vs 1740 cells/cu mm, $185.8 \mathrm{mg} / \mathrm{L}$ vs $31.7 \mathrm{mg} / \mathrm{L}, 17.1$ vs $996.3,552.8 \mathrm{IU} / \mathrm{L}$ vs $252.7 \mathrm{IU} / \mathrm{L}$, $2531.9 \mathrm{ng} / \mathrm{ml}$ vs $414.1 \mathrm{ng} / \mathrm{ml}$ and $2245.5 \mathrm{ng} / \mathrm{ml}$ vs $339.4 \mathrm{ng} / \mathrm{ml}$ respectively.
\end{abstract}

Conclusion: An increased NLR, CRP, LDH, Ferritin and D-dimer and a reduced ALC and LCR are significantly associated with disease severity, need for ICU and mortality. These biomarkers will be useful adjunct to clinical assessment in better categorising and management of COVID-19 patients.

Keywords: Biomarkers; COVID-19; CRP; D-dimer; NLR; ferritin; SARS.

\section{INTRODUCTION}

$\mathrm{T}$ he world witnessed a surge of pneumonia cases of unknown etiology, emerging from Wuhan in Hubei province of China during the early December 2019 (1). The Chinese Centre for Disease Control and Prevention conducted high-throughput sequencing on the throat swab sample of patients with this disease and reported the etiology of pneumonia as a novel beta-coronavirus(2) which causes a disease resembling severe acute respiratory syndrome coronavirus(SARS-CoV; 3). Subsequently this pandemic disease was named as 2019-novel coronavirus disease (COVID-19) and the culprit virus was named severe acute respiratory syndrome coronavirus 2 (SARS-CoV-2) by the World Health Organisation(WHO). The first case in India was reported on January 30, 2020 from Thrissur in Kerala. Of all the confirmed COVID-19 cases in India, 1009976 are active, 4025079 are discharged and 83198 deaths reported as on $17^{\text {th }}$ September $2020(5)$.

People infected with this pandemic causing virus may present with a myriad of clinical features in isolation or combination, ranging from mild symptoms like fever, anosmia, cough, myalgia, sputum production, headache, haemoptysis, diarrhoea to severe symptoms like dyspnoea, acute respiratory distress
syndrome(ARDS), acute cardiac injury or secondary infection $(5,6)$. Due to such varied clinical presentation among patients infected with novel beta- coronavirus, subjectivity in assessing clinical condition and rapid deterioration in the disease course, the role of biomarkers becomes more important. Some of the biomarkers, which provide objective values through the disease progression, can help in interpretation of symptoms and better categorising of patients allowing earlier interventions $(7,8)$. Simple and cost-effective biomarkers, if found useful can be of great help especially in developing countries with limited resources catering to a large population. On the other hand, biomarkers are ordered routinely by some clinicians in COVID-19 patients. As such, it becomes important to understand the association between these biomarkers and disease. The dynamic fluctuation in the levels of the biomarkers and disease severity needs close follow-up through the entire course of the disease i.e., till recovery or death.

Hence, we conducted a complete follow-up study to explore the role of different biomarkers like the Neutrophil-lymphocyte ratio (NLR), C-reactive protein (CRP), Ferritin, D-dimer, Lactate dehydrogenase (LDH), and Lymphocyte to CRP ratio 
(LCR) in COVID-19 patients and their association with disease severity.

\section{MATERIALS AND METHODS}

This was a cohort study conducted in Father Muller Medical College Hospital, which is a tertiary care hospital located in Mangalore city of Dakshina Kannada district of Karnataka state in southern part of India. The institution ethical clearance was obtained. We included all consecutive COVID-19 patients admitted from June $1^{\text {st }} 2020$ to July $31^{\text {st }} 2020$. The paediatric patients and patients with lost follow-up were excluded. COVID-19 was confirmed microbiologically by reverse transcriptase polymerase chain reaction (RT-PCR) or by Cartridge Based Nucleic Acid Amplification Test (CB-NAAT).

Clinical data, laboratory parameters and outcome from consecutive patients with microbiologically confirmed COVID-19 were collected from the records. The hospital had no control over patient selection and patients of all severity were admitted. Patients were received and evaluated in screening areas like fever clinic and casualty. History related to travel, exposure and presence of co-morbidities was taken and documented. The patients were triaged and admitted in hospital as per the clinical assessment into isolation ward or the intensive care units (ICU). During the course of stay in ward, need for clinician depending on the patients disease severity, age and accompanying co-morbidities decided ICU.

All the patients were treated symptomatically according to the standard guidelines at that point of time. Treatment for pre-existing diseases was continued. Baseline laboratory investigations were done. From all the patients suspected of COVID-19, throat swab and nasopharyngeal samples were taken and sent to the molecular testing laboratory of our Hospital, in viral transport medium with proper packaging and all precautions. The samples were processed in a biological safety cabinet (BSC-type IIb). RNA extraction was done by reverse transcriptase-polymerase chain reaction (RT-PCR) and Qualitative RT-PCR targeting the envelope (E), open reading frame $1 \mathrm{~b}$ (ORF-1b) and RNA-dependent RNA polymerase (RdRp2) genes of SARS-CoV-2 was performed.

The laboratory biomarkers namely the complete blood counts, CRP, LDH, D-dimer and Ferritin were done in all patients at admission and before discharge and in between depending on the clinical condition of the patient. The worst value of these biomarkers was taken in our study. The patients clinical condition and severity was categorised using the Centre for Disease Control and Prevention (CDC) guidelines update as on June 30, 2020 (9) as Mild to moderate (Mild symptoms up to mild pneumonia) or Severe disease (dyspnoea, hypoxia or $>50 \%$ lung involvement on imaging) or Critical illness (respiratory failure, shock or multiorgan failure). All the patients were followedup till the end-point i.e., discharge or death. Severity was assessed during the entire course of hospital stay and the worst was recorded. Analysis was done between Severe vs Non-severe groups, ICU vs NonICU groups and Recovered/discharged vs Dead groups. Patients with mild or moderate disease were categorised into the Non-severe group, and patients with severe or critical disease were included in the severe group. Patients requiring ICU care at any point of their stay in the hospital were included in the ICU group. The outcomes were recorded as recovered or dead.

\section{Statistical analysis}

Continuous data were presented as mean and standard deviation (SD) for normally distributed data. For nonnormallt distributed data, median and interquartile range (IQR) were used. Categorical variables were presented by frequency and percentages $(\mathrm{n} \%)$. Comparability between groups was analysed by Mann Whitney U test. The IBM SPSS version 23 software was used for statistical analyses. Receiver operating characteristic (ROC) curve was plotted for NLR, CRP, LDH and Ferritin. Area under the curve (AUC) and cut-off values were calculated.

\section{RESULTS}

A total of 336 with COVID-19 were hospitalised during the study period. Of these, 16 patients were not analysed ( 3 were paediatric cases, 4 were still admitted and 9 patients were either referred or discharged against medical advice).

Of the 320 cases, 197 patients $(61.6 \%)$ were males. Mean age of patients was 44.82 years and $30 \%$ were below 30 years of age. The elderly (>60 years) contributed to $18.4 \%$ of the admissions (Table 1).

Table 1: Clinical and Demographic profile of patients admitted with COVID-19

\begin{tabular}{|c|c|c|}
\hline \multicolumn{2}{|c|}{} & Number (percentage) \\
\hline \multirow{3}{*}{ Age } & 30 and below & $97(30.3)$ \\
\cline { 2 - 3 } & $31-40$ & $41(12.8)$ \\
\cline { 2 - 3 } & $41-50$ & $53(16.6)$ \\
\cline { 2 - 3 } & $51-60$ & $70(21.9)$ \\
\cline { 2 - 3 } & Above 60 & $59(18.4)$ \\
\hline \multirow{5}{*}{ Gender } & Male & $197(61.6)$ \\
\cline { 2 - 3 } & Female & $123(38.4)$ \\
\hline ICU And Non-ICU & Non ICU & $271(84.7)$ \\
\hline
\end{tabular}




\begin{tabular}{|c|c|c|}
\hline \multirow{3}{*}{ Severity } & ICU & $49(15.3)$ \\
\hline \multirow{4}{*}{} & Asymp & $48(15.0)$ \\
\cline { 2 - 3 } & Mild & $168(52.5)$ \\
\cline { 2 - 3 } & Moderate & $65(20.3)$ \\
\cline { 2 - 3 } & Severe & $20(6.3)$ \\
\cline { 2 - 3 } & Critical & $19(5.9)$ \\
\hline Outcome & Recovered & $303(94.7)$ \\
\cline { 2 - 3 } & Dead & $17(5.3)$ \\
\hline
\end{tabular}

Approximately one-third $(31.8 \%)$ of the patients admitted had Diabetes mellitus as one of the comorbidities. Mean age was 57 years. Severe and critical disease was observed in 22 of them. Mortality rate in this sub-group was $12.7 \%$, which is more than two times the overall mortality rate.

The other co-morbidities, which were observed in patients, were Hypertension, Kidney disease, Heart disease, Hypothyroidism, Lung disease and Malignancies.

Using CDC criteria, 168 patients $(52.5 \%)$ had mild disease. Moderate, Severe and Critical disease was seen in $65(20.3 \%), 20(6.3 \%)$ and $19(5.9 \%)$ patients respectively. Forty-eight (15\%) of cases were asymptomatic. ICU care was required for $49(15.3 \%)$ patients. Overall mortality was $5.3 \%$. Among patients with severe and critical disease (12.2\%), mortality was observed in $43 \%$ of cases. Mortality was $12.7 \%$ in diabetics and $20.8 \%$ in patients with heart disease.

CRP, LDH, Ferritin and D-dimer were found to be significantly elevated in patients who developed severe disease as compared to those with non-severe disease. (CRP - $185.82 \mathrm{mg} / \mathrm{L}$ vs $31.77 \mathrm{mg} / \mathrm{L}, \mathrm{LDH}-$ $522.8 \mathrm{IU} / \mathrm{L}$ vs $252.7 \mathrm{IU} / \mathrm{L}$, Ferritin - $2531.9 \mathrm{ng} / \mathrm{ml}$ vs $414 \mathrm{ng} / \mathrm{ml}$, D-dimer - $2245.4 \mathrm{ng} / \mathrm{ml}$ vs $339.4 \mathrm{ng} / \mathrm{ml}$ ).

The elevated biomarkers were significantly associated with need for ICU care and mortality (Table 2).

Table 2: Median and Inter-quartile range [IQR] of Biomarkers in patients admitted with COVID-19.

\begin{tabular}{|c|c|c|c|c|c|c|}
\hline $\begin{array}{c}\text { Biomarker } \\
\text { Median [IQR] }\end{array}$ & Severe & Non- severe & ICU & Non-ICU & Recovered & Dead \\
\hline $\begin{array}{l}\text { Total White cell } \\
\text { count in cells/ } \\
\text { cumm [IQR] }\end{array}$ & $\begin{array}{c}14400 \\
{[12100-} \\
18200]\end{array}$ & $\begin{array}{c}5900 \\
{[4700-8550]}\end{array}$ & $\begin{array}{c}13700 \\
{[11950-} \\
17200]\end{array}$ & $\begin{array}{c}5800 \\
{[4700-} \\
8300]\end{array}$ & $\begin{array}{c}6000 \\
{[4800-9425]}\end{array}$ & $\begin{array}{c}16100 \\
{[13150-20050]}\end{array}$ \\
\hline $\begin{array}{c}\text { NLR(Neutrophil } \\
\text { to Lymphocyte } \\
\text { ratio) [IQR] }\end{array}$ & $\begin{array}{c}14.50 \\
{[7.9-19]}\end{array}$ & $\begin{array}{c}2.42 \\
{[1.41-4.33]}\end{array}$ & $\begin{array}{c}12.86 \\
{[7.32-18.90]}\end{array}$ & $\begin{array}{c}2.33 \\
{[1.39-4.13]}\end{array}$ & $\begin{array}{c}2.51 \\
{[1.47-5.51]}\end{array}$ & $\begin{array}{c}17.20 \\
{[12.79-31.00]}\end{array}$ \\
\hline $\begin{array}{l}\text { ALC (Absolute } \\
\text { lymphocyte count } \\
\text { in cells/cumm) } \\
{[\mathrm{IQR}]}\end{array}$ & $\begin{array}{c}896 \\
{[660-1176]}\end{array}$ & $\begin{array}{c}1565 \\
{[1117-2108]}\end{array}$ & $\begin{array}{c}910 \\
{[652-1222]}\end{array}$ & $\begin{array}{c}1585 \\
{[1122-} \\
2107]\end{array}$ & $\begin{array}{c}1519 \\
{[1088-2100]}\end{array}$ & $\begin{array}{c}732 \\
{[550-977]}\end{array}$ \\
\hline $\begin{array}{c}\mathrm{CRP} \text { in } \mathrm{mg} / \mathrm{L} \\
\text { [IQR] }\end{array}$ & $\begin{array}{l}129.57 \\
{[64.77-} \\
264.69]\end{array}$ & $\begin{array}{c}6.72 \\
{[1.55-44.34]}\end{array}$ & $\begin{array}{l}118.73 \\
{[60.07-} \\
238.56]\end{array}$ & $\begin{array}{r}6.28 \\
{[1.44-} \\
38.53] \\
\end{array}$ & $\begin{array}{c}9.58 \\
{[1.78-54.83]}\end{array}$ & $\begin{array}{c}171.48 \\
{[117.58-293.71]}\end{array}$ \\
\hline $\begin{array}{c}\text { LCR(Lymphocyte } \\
\text { to CRP ratio) } \\
\text { [IQR] }\end{array}$ & $\begin{array}{c}7.4[2.79- \\
13.89]\end{array}$ & $\begin{array}{c}230.28 \text { [31.8- } \\
1193.88]\end{array}$ & $\begin{array}{c}7.93 \\
{[2.98-15.09]}\end{array}$ & $\begin{array}{c}273.72 \\
{[39.58-} \\
1268.99]\end{array}$ & $\begin{array}{c}170.62 \\
{[22.66-1045.16]}\end{array}$ & $\begin{array}{c}2.97 \\
{[2.19-8.37]}\end{array}$ \\
\hline $\begin{array}{c}\text { LDH in IU/L } \\
{[\text { IQR }]}\end{array}$ & $\begin{array}{c}508[337.5- \\
685]\end{array}$ & $\begin{array}{c}222 \\
{[185.5-295.5]}\end{array}$ & $\begin{array}{c}421 \\
{[325-656]}\end{array}$ & $\begin{array}{c}219 \\
{[184-292]}\end{array}$ & $\begin{array}{c}228.50 \\
{[188-313.75]}\end{array}$ & $\begin{array}{c}637.50 \\
{[359.50-977.75]}\end{array}$ \\
\hline $\begin{array}{c}\text { Ferritin in ng/ml } \\
{[\mathrm{IQR}]}\end{array}$ & $\begin{array}{c}901.95 \\
{[493.38-} \\
2116.25]\end{array}$ & $\begin{array}{c}213.9 \\
{[74.88-} \\
486.10]\end{array}$ & $\begin{array}{c}760.10 \\
{[380.45-} \\
1598.50]\end{array}$ & $\begin{array}{l}207.40 \\
{[73.39-} \\
473.35]\end{array}$ & $\begin{array}{c}234.50 \\
{[80.56-523.40]}\end{array}$ & $\begin{array}{c}1338 \\
{[599.18-} \\
4320.50]\end{array}$ \\
\hline $\begin{array}{c}\text { D-dimer in } \mathrm{ng} / \mathrm{ml} \\
{[\mathrm{IQR}]}\end{array}$ & $\begin{array}{c}916.5[307- \\
3647]\end{array}$ & $\begin{array}{c}156 \\
{[100-326]}\end{array}$ & $\begin{array}{c}901 \\
{[307-2817]}\end{array}$ & $\begin{array}{c}146.5 \\
{[100-305]}\end{array}$ & $\begin{array}{c}163 \\
{[100-396]}\end{array}$ & $\begin{array}{c}1426 \\
{[673-3353]}\end{array}$ \\
\hline
\end{tabular}

ManWhitney test $\mathrm{P}$ value $<0.001$ was highly significant for all the biomarkers for Severe vs Nonsevere, ICU vs non-ICU and Recovered vs Dead.

An increased total WBC count and NLR was significantly associated with severe disease, need for ICU, and mortality. Decreased ALC and LCR were significantly associated with severe disease, ICU requirement and mortality. An inverse correlation was noted between ALC, LCR and other biomarkers.
Elevated levels of CRP, LDH, Ferritin, D-dimer were significantly associated with increased severity, need for ICU care and mortality. AUC for four biomarkers namely NLR, CRP, LDH and Ferritin were found to be significantly different between severe vs nonsevere, ICU vs non-ICU and recovered vs dead groups. (Fig. 1, 2, 3). 


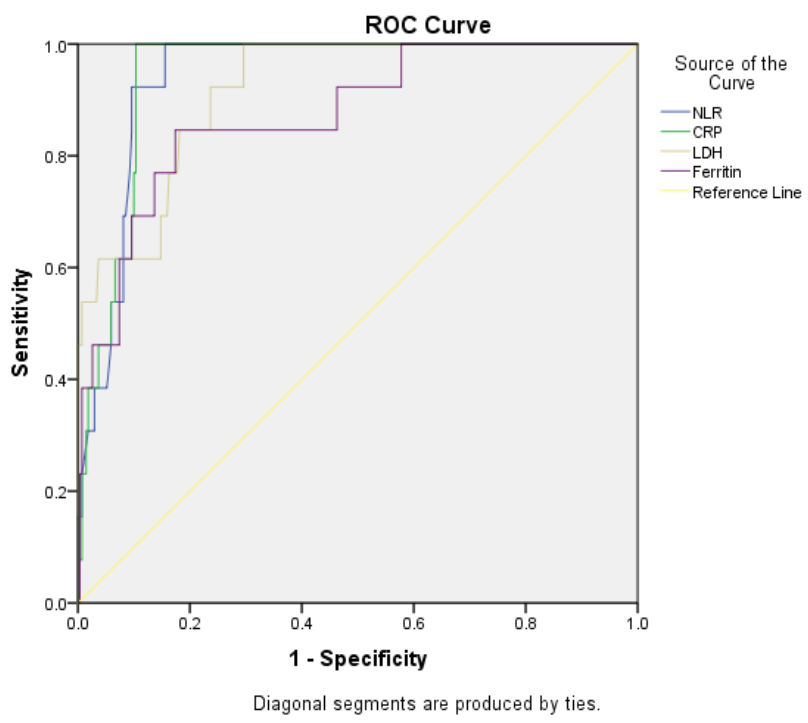

Fig. 1: ROC - Recovered vs Dead

\begin{tabular}{|c|c|c|c|}
\hline \multicolumn{5}{|c|}{ AUC and Cut-off values for Biomarkers: } \\
Recovered vs Dead
\end{tabular}

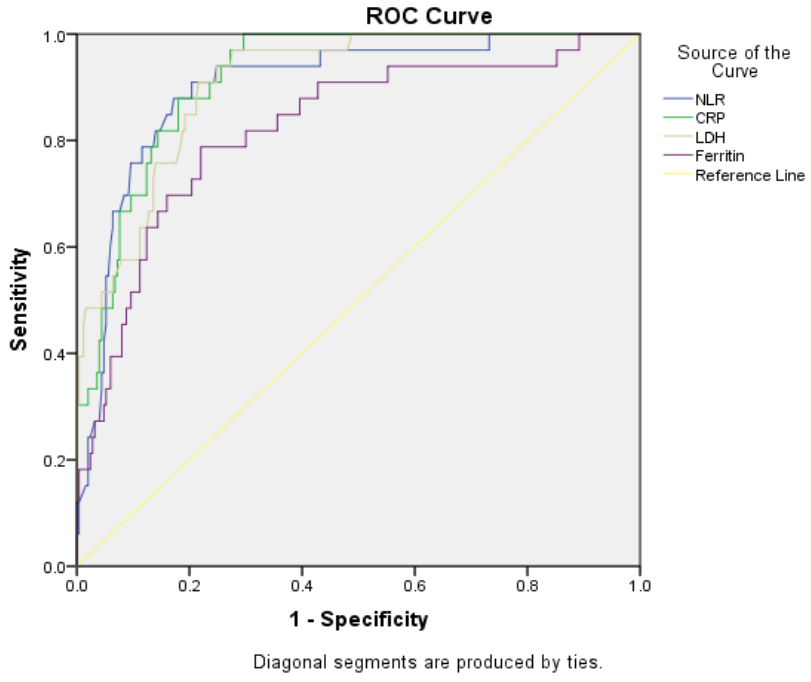

Fig. 2: ROC Severe vs Non-severe groups

\begin{tabular}{|c|c|c|c|}
\hline \multicolumn{4}{|c|}{$\begin{array}{c}\text { AUC and Cut-off values for Biomarkers: } \\
\text { Severe vs Non-severe groups }\end{array}$} \\
\hline Biomarkers & $\begin{array}{c}\text { Area under } \\
\text { curve }\end{array}$ & $\begin{array}{c}\text { Std. } \\
\text { Error }\end{array}$ & $\begin{array}{c}\text { Cut-off } \\
\text { value }\end{array}$ \\
\hline NLR & .902 & .027 & 5 \\
\hline CRP & .918 & .019 & 57.5 \\
\hline LDH & .910 & .022 & 322.5 \\
\hline Ferritin & .823 & .041 & 391.5 \\
\hline
\end{tabular}

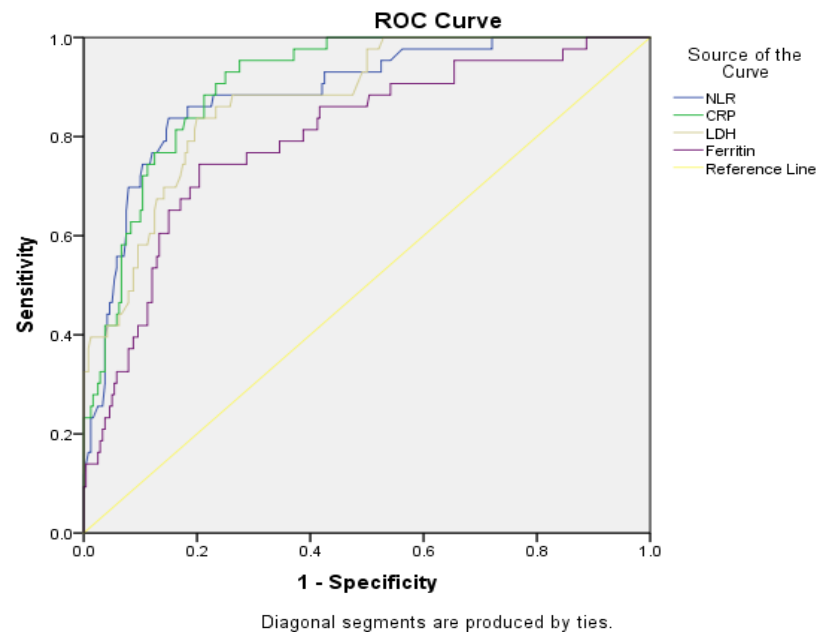

Fig. 3: ROC - ICU vs Non-ICU groups

\begin{tabular}{|c|c|c|c|}
\hline \multicolumn{4}{|c|}{ AUC and Cut-off values for Biomarkers: ICU vs } \\
Non-ICU groups \\
\hline Biomarkers & $\begin{array}{c}\text { Area under } \\
\text { curve }\end{array}$ & $\begin{array}{c}\text { Std. } \\
\text { Error }\end{array}$ & $\begin{array}{c}\text { Cut-off } \\
\text { value }\end{array}$ \\
\hline NLR & .886 & .027 & 4.2 \\
\hline CRP & .907 & .019 & 44.7 \\
\hline LDH & .875 & .026 & 291.5 \\
\hline Ferritin & .798 & .037 & 294.5 \\
\hline
\end{tabular}

\section{DISCUSSION}

We reported the epidemiological profile, disease severity, biomarkers and outcome of a cohort of 320 consecutive patients admitted in a tertiary care hospital in southern part of India. The mean age of our patients was 44.82 years, which is comparable to an Indian study (10) and lower as compared to studies from other countries $(4,11-14)$. Our study had a male predominance $(61.6 \%)$ which was comparable to studies from other countries (Table 3).

Table 3: Mean age of COVID-19 patients from various studies

\begin{tabular}{|c|c|c|c|}
\hline Study & Mean age (year) & Males, $\mathrm{n}(\%)$ & Outcomes \\
\hline Huang et al.., $4(\mathrm{n}=41)$ & 49 & $30(73)$ & ICU - 32\%; Death - $15 \%$ \\
\hline Mohan A et al., $10(n=144)$ & 40.1 & $134(93.1)$ & ICU $-2.8 \%$; Death $-1.4 \%$ \\
\hline Guan et al., $11(\mathrm{n}=1099)$ & 47 & $637(58.1)$ & $\begin{array}{c}67 \text { patients reached composite end } \\
\text { point of which } 15 \text { died }\end{array}$ \\
\hline Wang D et al., $12(\mathrm{n}=138)$ & 56 & $75(54.3)$ & $\begin{array}{c}\text { ICU }-36(26.1 \%) \\
6 \text { died, } 11 \text { were in ICU }\end{array}$ \\
\hline Chen $\mathrm{N}$ et al., $13(\mathrm{n}=99)$ & 55.5 & $67(68)$ & $\begin{array}{c}\text { ICU - 23(23\%) } \\
\text { 11(11\%) died and 57(58\%) were } \\
\text { still in hospital }\end{array}$ \\
\hline $\begin{array}{l}\text { Richardson et al., } 14 \\
\qquad(\mathrm{n}=5700)\end{array}$ & $63(52-75)$ & $3437(60.3)$ & $\begin{array}{l}2634 \text { reached study end-point. } \\
\text { 373(14.2\%) in ICU, } \\
\text { 553(21\%) died. }\end{array}$ \\
\hline Present study $(\mathrm{n}=320)$ & 44.82 & 197(61.6\%) & $\begin{array}{l}\text { ICU }-15.3 \% \\
\text { Death }-5.3 \%\end{array}$ \\
\hline
\end{tabular}


However, a study from Northern India reported a male predominance of $93.1 \%$. The authors attribute this to the fact that a significant number of their patients were part of a public gathering mainly attended by men, which was identified as a hotspot, and patients were identified by active screening (10).

Severe disease was seen in $12.2 \%$ of our patients, which is lower than that of other studies where severe disease was seen in 15.7 to $29 \%$ of all patients. $(4,11-$ 13). However, an Indian study reported a lower percentage $(2.8 \%)$ of severe disease among their study patients which the authors attribute to selection bias as majority of their patients were identified by active screening(10).

The rate of ICU admission among coronavirus infected patients ranges from 3\% to $100 \%$ as shown in a meta-analysis. The meta-analysis included thirtyseven studies with a total of 32,741 participants, conducted in different countries. The pooled rate of ICU admission was $32 \%$ with subgroup analysis that showed a rate of $32 \%, 57 \%$ and $26 \%$ for SARS-COV, MERS and SARS-COV-2 respectively. The authors say that one of the limitations of their meta-analysis is limited studies from few countries. There are no Indian studies included in the meta-analysis (15). The rate of ICU admission in our study was $15.3 \%$. The mortality rate and ICU requirement in our study and another Indian study (10) is less than studies done in other countries (Table 3 ).

Studies on White blood cell count (WCC) in COVID19 patients have shown variable results. Patients with RT-PCR positive COVID-19 disease had a significantly lower WCC as compared to RT-PCR negative suspect COVID-19 patients in a study of 200 patients.(16) In a retrospective study, an increase in WCC in severe group as compared to the non-severe group $\left(5.6\right.$ vs $\left.4.9 \times 10^{9} / \mathrm{L} ; \mathrm{p}<0.001\right)$. A greater neutrophil-to-lymphocyte ratio (NLR) of 5.5 was observed in severe group as compared to 3.2 in nonsevere group. (17) Another Chinese study concluded similar findings of high NLR in severe patients suggesting a role of NLR as a potential biomarker for severity in COVID-19.(12) In our study a significantly increased WCC and NLR were associated with increased severity, need for ICU care and mortality.

Absolute lymphocyte count (ALC) were reported to be lower in majority of COVID-19 patients in a descriptive study (13). Another study reported a lower lymphocyte count in critical patients suggesting a poor prognosis (18). In our study, a significantly lower ALC was associated with increased severity, ICU admission and death.

CRP is an acute phase reactant used as a biomarker in various inflammatory conditions. Though it is nonspecific, a rise in CRP levels is associated with increased disease severity (8). In a retrospective cohort study conducted in Wuhan, China, that included
COVID-19 patients, a significantly higher CRP levels were observed among severe patients $(57.9 \mathrm{mg} / \mathrm{L})$ as compared to non-severe patients $(33.2 \mathrm{mg} / \mathrm{L})$ with a $\mathrm{p}<0.001$ (17). Another retrospective cohort study on progression in severity of COVID-19 patients, it was found that CRP levels greater than $41.8 \mathrm{mg} / \mathrm{L}$ was associated with increased likelihood of severe disease (19). In a study on computed tomography(CT) findings and CRP levels between two groups, one of COVID-19 patients and the other of influenza A or B patients, it was observed that the CRP levels was a better early predictor of severe COVID-19 disease with a sensitivity of $83 \%$ and a specificity of $91 \%(20)$. In a retrospective cohort study of 150 COVIDpatients, that studied disease outcomes and biomarker levels, it was observed that CRP levels were significantly associated with mortality (21). Our study also showed similar results.

Lactate dehydrogenase (LDH) is another biomarker, which has convincing evidence between its serum levels and severity in COVID-19 in a Italian study involving 141 patients (22). In a single- centre retrospective cohort study involving 42 COVID-19 patients, a significant positive correlation was observed between LDH, CRP, Erythrocyte sedimentation rate and the severity of pneumonia as assessed on the initial CT images (23). In a retrospective study of 155 COVID-19 patients categorised into general and refractory groups, a higher level of LDH ( $p=0.017)$, CRP ( $p=0.001)$, AST and neutrophil count were reported in the refractory group. These findings are consistent with our results.

Some studies have observed elevated levels of Ddimer in COVID-19 patients requiring ICU admission and invasive ventilation $(4,11)$. In a follow-up study of 183 patients with an overall mortality rate of $11.5 \%$, a significantly higher levels of D-dimer and fibrin degradation product levels were observed in the nonsurvivors (25). Our study also found that elevated Ddimer was associated with poor outcomes. Higher Ddimer levels predict poor prognosis and can therefore serve as an early biomarker and help the clinician in better management $(26,27)$.

Studies on platelet count and severity in COVID-19 have shown variable results. A lower platelet count was found to be associated with increased severity and mortality in COVID-19 patients. $(28,29)$ Contrary to these studies a higher platelet count was observed in the severe group of patients with COVID-19 $(4,30)$. Our study found no association between platelet count and disease severity.

In a retrospective study conducted in China, increased serum ferritin levels were seen in 63\% of COVID-19 cases with a mean level of $808.7 \mathrm{ng} / \mathrm{ml}$ (13). We also found that elevated serum ferritin levels had association with severity, ICU admission and mortality. 


\section{Limitation}

This is a single-centre study and only the hospitalised patients are included.

\section{CONCLUSION}

To conclude, the biomarkers like NLR, CRP, Ferritin, D-dimer, LDH and LCR are associated with disease severity, need for ICU care and mortality. These biomarkers can be performed routinely in all COVID19 patients and can be used as an adjunct to clinical examination in better categorising patients who need ICU care and aggressive management.

\section{CONFLICTS OF INTEREST}

Authors declare no conflict of interest.

\section{REFERENCES}

1. Li, Q., Guan, X., Wu, P., Wang, X., Zhou, L., Tong, Y., et al., Early Transmission Dynamics in Wuhan, China, of Novel Coronavirus-Infected Pneumonia. N Engl J Med. 2020 Mar 26; 382(13): 1199-1207.

2. Lu, H., Stratton, C. W., Tang, Y. W. Outbreak of pneumonia of unknown etiology in Wuhan, China: The mystery and the miracle. J Med Virol. 2020 Apr; 92(4): 401-402.

3. Hui, D. S., Azhar, E., Madani, T. A., Ntoumi, F., Kock, R., Dar, O., et al., The continuing 2019-nCoV epidemic threat of novel coronaviruses to global health - The latest 2019 novel coronavirus outbreak in Wuhan, China. International Journal of Infectious Diseases. 2020 Feb; 91: 264-266.

4. Huang, C., Wang, Y., Li, X., Ren, L., Zhao, J., Hu, Y., et al., Clinical features of patients infected with 2019 novel coronavirus in Wuhan, China. Lancet. 2020 Feb 15; 395(10223): 497-506.

5. Mohfw.gov.in. [homepage on the Internet]. Ministry of Health and Family Welfare Government of India [updated 2020 Sep 17]. Available from https://www.mohfw.gov.in/, accessed on Sep 17, 2020.

6. Zaim, S., Chong, J. H., Sankaranarayanan, V., Harky, A. COVID-19 and Multiorgan Response. Curr Probl Cardiol. 2020 Aug; 45(8): 100618.

7. Pierce, J. D., McCabe, S., White, N., Clancy, R. L. Biomarkers: an important clinical assessment tool. Am J Nurs. 2012 Sep; 112(9): 52-58.

8. Gong, J., Dong, H., Xia, S. Q., Huang, Y. Z., Wang, D., Zhao, Y. Correlation analysis between disease severity and inflammation-related parameters in patients with Covid-19 Pneumonia. 2020 Feb 27. medRxiv. 2020.02.25.2002564

9. Cdc.gov. [homepage on the Internet]. Centers for Disease Control and Prevention [updated 2020 June 30]. Available fromhttps://www.cdc.gov/coronavirus/2019-ncov/hcp/ clinical-guidance-management-patients.html, accessed on June 30, 2020.

10. Mohan, A., Tiwari, P., Bhatnagar, S., Patel, A., Maurya, A., Dar, L., et al., Clinico-demographic profile \& hospital outcomes of COVID-19 patients admitted at a tertiary care centre in north India. Indian J Med Res. 2020 Sep; 152(1): 61-69.

11. Guan, W. J., Ni, Z. Y., Hu, Y., Liang, W. H., Ou, C. Q., He, J. X., et al., Clinical characteristics of coronavirus disease 2019 in China. N Engl J Med 2020; 382 : 1708-1720.

12. Wang, D., Hu, B., Hu, C., Zhu, F., Liu, X., Zhang, J., et al., Clinical characteristics of 138 hospitalized patients with 2019 novel coronavirus-infected pneumonia in Wuhan, China. JAMA. 2020; 323: 1061-1069.

13. Chen, N., Zhou, M., Dong, X., Qu, J., Gong, F., Han, Y., et al., Epidemiological and clinical characteristics of 99 cases of 2019 novel coronavirus pneumonia in Wuhan, China: A descriptive study. Lancet 2020; 395: 507-513.
14. Richardson, S., Hirsch, J. S., Narasimhan, M., Crawford, J. M, McGinn, T., Davidson, K. W., et al., Presenting characteristics, comorbidities, and outcomes among 5700 patients hospitalized with COVID-19 in the New York City area. JAMA 2020; 323: 2052-2059.

15. Abate, S. M., Ahmed, Ali, S., Mantfardo, B., Basu, B. Rate of Intensive Care Unit admission and outcomes among patients with coronavirus: A systematic review and Metaanalysis. PLoS One. 2020 Jul 10; 15(7): e0235653.

16. Mardani, R., Ahmadi Vasmehjani, A., Zali, F., Gholami, A., Mousavi Nasab, S. D., Kaghazian, H., et al., Laboratory parameters in detection of Covid-19 patients with positive RT-PCR; a diagnostic accuracy study. Arch Acad Emerg Med. 2020 Apr 4; 8(1): e43.

17. Qin, C., Zhou, L., Hu, Z., Zhang, S., Yang, S., Tao, Y., et al., Dysregulation of immune response in patients with coronavirus 2019 (Covid-19) in Wuhan, China. Clin Infect Dis. 2020 Jul 28;71(15):762-768.

18. Tan, L., Wang, Q., Zhang, D., Ding, J., Huang, Q., Tang, Y. Q., et al., Lymphopenia predicts disease severity of COVID19: a descriptive and predictive study. Signal Transduct Target Ther. 2020 Mar 27; 5(1): 33.

19. Liu, F., Li, L., Xu, M., Wu, J., Luo, D., Zhu, Y., et al., Prognostic value of interleukin-6, C-reactive protein, and procalcitonin in patients with Covid-19. J Clin Virol. 2020 Jun; 127: 104370.

20. Tan, C., Huang, Y., Shi, F., Tan, K., Ma, Q., Chen, Y., et al., C-reactive protein correlates with computed tomographic findings and predicts severe Covid-19 early. J Med Virol. $2020 \mathrm{Jul}$; 92(7): 856-862.

21. Ruan, Q., Yang, K., Wang, W., Jiang, L., Song, J. Clinical predictors of mortality due to Covid-19 based on an analysis of data of 150 patients from Wuhan, China. Intensive Care Med. 2020 May; 46(5): 846-848.

22. Ferrari, D., Motta, A., Strollo, M., Banfi, G., Locatelli, M. Routine blood tests as a potential diagnostic tool for Covid19. Clin Chem Lab Med. 2020 Jun 25; 58(7): 1095-1099.

23. Xiong, Y., Sun, D., Liu, Y., Fan, Y., Zhao, L., Li, X., et al., Clinical and high-resolution ct features of the covid-19 infection: comparison of the initial and follow-up changes. Invest Radiol. 2020 Jun; 55(6): 332-339.

24. Mo, P., Xing, Y., Xiao, Y., Deng, L., Zhao, Q., Wang, H., et al., Clinical characteristics of refractory Covid-19 pneumonia in Wuhan, China. Clin Infect Dis. 2020 Mar 16: ciaa270.

25. Tang, N., Li, D., Wang, X., Sun, Z. Abnormal coagulation parameters are associated with poor prognosis in patients with novel coronavirus pneumonia. J Thromb Haemost. 2020 Apr; 18(4): 844-847.

26. Zhou, F., Yu, T., Du, R., Fan, G., Liu, Y., Liu, Z., et al., Clinical course and risk factors for mortality of adult inpatients with Covid-19 in Wuhan, China: a retrospective cohort study. Lancet. 2020 Mar 28; 395(10229): 1054-1062.

27. Zhang, L., Yan, X., Fan, Q., Liu, H., Liu, X., Liu, Z., et al. Ddimer levels on admission to predict in-hospital mortality in patients with Covid-19. J Thromb Haemost. 2020 Jun; 18(6): 1324-1329.

28. Young, B. E., Ong, S. W. X., Kalimuddin, S., Low, J. G., Tan, S. Y., Loh, J., et al., Singapore 2019 Novel Coronavirus Outbreak Research Team. Epidemiologic Features and Clinical Course of Patients Infected With SARS-CoV-2 in Singapore. JAMA. 2020 Apr 21; 323(15): 1488-1494.

29. Liu, Y., Sun, W., Guo, Y., Chen, L., Zhang, L., Zhao, S. Association between platelet parameters and mortality in coronavirus disease 2019: retrospective cohort study. Platelets. 2020 Apr 16; 0(0): 1-7.

30. Yang, X., Yu, Y., Xu, J., Shu, H., Xia, J., Liu, H. Clinical course and outcomes of critically ill patients with SARSCoV-2 pneumonia in Wuhan, China: a single-centered, retrospective, observational study. Lancet Respir. Med. 2020 Feb 24; 8(5): 475-481. 